\title{
DEVELOPMENT OF CZECH ECONOMIC THEORY FROM THE ASPECT OF DISCUSSIONS IN THE POLITICKÁ EKO- NOMIE JOURNAL (1953 - 1989)
}

\author{
Jiří ŘEZNÍ́*
}

\begin{abstract}
:
On the occasion of the 50th anniversary of establishment of the Politická ekonomie economic periodical six articles were published in 2003 reviewing the history, rise and fall of this journal in 1953 - 1989. This review presents to foreign readers a brief outline of economic thinking in this country in the period concerned that was reflected in articles published by Czech and Slovak economists in Politická ekonomie.
\end{abstract}

Keywords: history of economic thought, history of journal

JEL Classification: B20, A11

In 2003 the Politická ekonomie periodical celebrated the $50^{\text {th }}$ anniversary of its foundation. The goal of this article is to describe the picture of economics in $1953-$ 1989 that was presented to readership in two themes: the relationship of plan and market and the relation to standard economy. The great depression in the thirties of the $20^{\text {th }}$ century made economists argue against the statement about the need of replacing the competitive fight of manufacturers of goods by directive planning.

\section{Procrustean Bed of Single Orthodoxy (1953 - 1962 )}

"If the state did not observe the equation of price setting that the sum of prices equals the sum of values, the law of value would be enforced without restraint through failures, disproportions and uncontrolled setting of other than state prices, e.g. black-market prices or prices in the unorganised market." To this theorem formulated by Kraus (1953, pp. 134, 135) Šik responded (1953, p. 194): "Kraus ignores the restriction of the manufacture of goods under socialism". According to Burešová (1953, p. 204) "the function of the law of value operates in consumer demand in such a way that working people make a choice of utility values on the basis of their incomes". Stočes and Mysliveček (1955) advocated a more elastic price setting in agricultural commodities. This principle was argued against in an editorial

*) Milana Fialy 247/3, CZ-700 30 Ostrava-Dubina (e-mail: j.reznik@ volny.cz). 
article (1955, p. 188) where it was stated: "The masking of deficiencies in economic and organizational work through the action of economic laws brings grist to the mill of fetishism of the objectivity of economic laws and proclamation of government's lack of power. A tool of restriction of the regulatory function of the law of value is the level of economic and organizational work of the state." Taking into account that with the industrial production of socialist countries accounting for a third of the world industrial production the turnover of goods among these countries amounts to $8 \%$ of the world turnover, Kaigl (1956, pp. 245-247) wrote: "the problem of profitability shows that the law of value in the socialist system in which states are owners of goods influences not only circulation but also production. In trade with socialist countries prices in the world market should be considered. International division of labour becomes important for the USSR (Union of Soviet Socialist Republics). For us, it is a necessity. The goal is to surpass capitalist countries not only by per capita production of raw materials and energy resources but also by the effectiveness of utilization". In an article of the same author (1957, p. 695) about the influence of the Great October Socialist Revolution on development of economic science, in relation with the task "to forge it in a tool of revolutionary change of the world" a statement appeared that "development of the theory of socialism proceeded from recognition of the need of money and trade to the stage when factors of production are already considered as goods."

This formulation was preceded by a discussion about labour productivity at University of Economics in Prague (December 1956) that was focused on stimuli of productivity growth. Whereas the main proportions are set down by the state and while the state is not able to set down secondary proportions, enterprises should be made interested in production profitability. Disproportions between the interests of an individual and the whole cannot be removed by the introduction of competition relations between enterprises. Planning of prices and their influence on production and its innovations should become more elastic. But who will decide the prices - the state as an owner or the enterprises (see Petrovský, 1957).

To cope with the existence of surplus stock in the state trade sector and with the lack of knowledge of consumer demands Tošev (1958) suggested that prices would be set by vendors and their remuneration would be related to the economic result. According to Šik (1959) diversion of prices from the value of goods, i.e. a decrease (increase) in prices, makes it possible to increase (decrease) the consumption of those goods the need of which grows but whose relatively high value decelerates this consumption. It was stated in further discussion that the overestimation of administrative forms of management resulted in disturbances in economy. The motivation of individuals and enterprises clashed with the need of proportionality. Perspective planning was to be developed on a central level. Enterprises had to group into production and economic entities that were to dispose of in advance set shares in produced resources and that were to be able to fulfil tasks of the plan.

An editorial article (1958) accentuated the role of planning in the introduction of socio-economic changes of qualitative type contrary to general regulation of economy (planning theorem). Oliva (1959) rejected the idea of decisions of enterprises on incomes, investments and prices, even at the cost of decreasing employees' material interest, because it would interfere with the state ownership and enterprises would be matched against each other as owners. According to Vejvoda $(1958,1959)$ state enterprises realise their own reproduction process. The relation of demand and supply in the form of economic contracts is limited by the framework of central plan.

In a discussion about Vejvoda's model (see Suchan, 1959) Kadlec stated that the purchase and sale of goods were agreed on by individuals, therefore it was not possible to see the relations between social classes in them (Kadlec's theorem). 
Oliva was convinced that the exchange of goods between state enterprises was not possible when the owner of these goods was society, balance between the sum of market fund prices and purchase fund was controlled by the state, price influenced demand but it was not an economic category (Oliva's theorem of the impossibility of exchange in directive economy). According to Spišiak the increase in operative autonomy of enterprises will cause that enterprises will be subject to the state only in cardinal issues (Spišiak's hypothesis). In Sláma's opinion the disposition of money corresponding to the created value would lead to a change of enterprises into owners. According to Jóž we are not able to produce consumer goods in such proportions that are demanded by the population; it reveals deficiencies in planning, and the exchange of goods between countries conserves the quantitative aspect of the manufacture of goods (Jóža's planning syndrome). According to Spišiak (1960) the state bank cannot be identified with the state, which was an impulse to formulate the theory of monetary centre.

Kočí (1961, pp. 322-323) advocated this opinion: "Regardless of their farming results producers in agricultural cooperatives should be provided with the living standard on the level corresponding to that of the other working people; it ensues from a necessity to ensure agricultural production in an output corresponding to the needs of society. A failure to cope with this task would result in land abandonment and a decrease in producers' interest in production. To ensure these conditions implies to create conditions for extended reproduction of their production in all producers in agriculture."

Vlach (1960) discussed individual choice and its context on an example of the decision of a woman and a family (no child, one child or several children) whether she had to stay at home or go to work, he analysed its prerequisites, effects, costs and consequences. Rypota (1960, p. 119) generalised Tošev's requirement for the status of an enterprise by outlining the theory of conflict between individual and social interests ensuing from the particular variants of the relation between several estate and state ownership (e.g. an assumption of exclusive existence of cooperate ownership) and its expressions (enterprise khozraschot). Under these conditions "the social aspect of labour is reflected after all in the market". Henceforward it was possible to consider social interest and social ownership as an intersection of individual and group interests (ownership), and vice versa.

\section{Research Reorientation and Selucký's Simplism $(1962-1966)$}

According to V. S. Němčinov's remark "the purposeful application of social laws is typical of socialist society. This is the reason why the society poses special engineering demands on economists. They should know to conduct economic processes, to measure work, costs, consumption, etc. Economists must become social engineers" (see Skolka, 1962, p. 628). Kraus was convinced (1962, p. 938) that it was illusory to think that the state knew the value of products so that the prices were set either to equal this determined value or to depart from it intentionally. Until then nobody had been able to calculate the value of a single product nor the variance of the price from the value. We were able to calculate costs plus profit in enterprises, but it did not equal the value of products.

Misař (1962, pp. 489-490, 486) paid attention to unrealised purchasing power as a result of increasing savings: "Both the volume of deposits and their increment grow more quickly than average wages and wage fund in the socialist sector, and more quickly than the incomes of the population, employees saved more money than workers. If the supplies of consumer goods to the 
home market were not sufficiently high in relation to effective demand, purchasing power was accumulated in the form of either deposits or stored up money with the population that freeze in this form because savings could not be realised. The role of savings is determinant for reproduction orientation".

Indra (1962, p. 760) noticed that the effort aimed at planned coordination conflicted with parallelism in the building of industry in the countries of Council for Mutual Economic Assistance (CMEA), unfinished construction, local interests, underdeveloped agriculture, increase in stocks, delayed supplies of consumer goods, higher increase in the costs of pension scheme, deformation of the system of management from 1958, and with underestimation of the need to improve economic instruments. "The situation requires to carry out interventions that are not in accordance with the concept of economic policy and, in fact, they are the method of robbing Peter to pay Paul".

This situation led to analyses of the unanticipated development of planned economy, i.e. of its suppressed inflation potential (Kodet, 1964), stagnation of labour productivity and national income (Šik, 1966) that indicated that the centre was not able to control economy effectively. This resulted in considerations about socialist enterprise. The limits of this trend of thinking were described by Selucký (1963, pp. $14,11)$, for whom socialism was "a society based on the manufacture of goods". According to him, shareholders (in capitalism) were not "a less parasitic class than magnates previously".

The analysis of Indra's periodic difficulties aroused a discussion about how to increase the research level because "the complexity of economic relations and demands on the level of management work require to use scientific methods" (1963, p. 33). Economists asked about the limits of mathematics use.

Political economy describes regularities in qualitative terms although their nature is quantitative. Simulations are used for the investigation of microeconomic problems. Against these statements Oliva formulated a thesis that microeconomics would become economics in connection with social phenomena. An attack against the exactness of political economy is an attack against the labour theory of value (Oliva's dogma): "Assumptions, definitions, conclusions and theorems are exact (are not exact) if their content, and the methods leading to them, are (are not) clearly defined" (1964, pp. 299, 301).

According to Korda (1964, pp. 538-541) "without mathematics science is destined for stagnation. Can anybody say what the consequences of renewal of value relations to this or that extent will be like?" According to Oliva (1964, pp. 542, 547, 554) "exactness is not quantitative only. Controversial problems do exist (manufacture of goods, money and credit) but prove that it is a dogmatism." Participants in the discussion talked about the law of value and prices, about proportionality and planning because at that time economists examined the object of their interest in order not to describe "the consecution of the qualitative aspect of phenomena but to work out quantitative characteristics of reproduction process, to design the shape of specific functions of time, which was to support the purposeful behaviour of the society" (Paikert, 1963, p. 15).

Kýn (1964, pp. 542, 547, 554) wrote: "Objective conditions determine the limits within which the plan is defined. There exist many scenarios of plans there, and it is necessary to choose an optimum plan out of them according to a criterion. If two different criteria are chosen, two trajectories of development will be available that will differ from each other only little, but after some time the differences may be substantial and they will not exist only in the quantity of products but they will be projected into social forms. What the future society will be like also depends on today's decisions." According to Misař (1963, pp. 644-649) "there are limits of the economy that cannot be exceeded at any level of planning activity." 
Indra's periodic difficulties made economists think about models of national economy management. Models of economy functioning as a self-regulating mechanism were presented for discussion: either model (Vejvoda, 1964) assuming directive management or model (Komenda-Kožušník, 1964) abandoning directive management. According to first model the economic interest of an enterprise was to be based on achievement of an extraordinary value. Second model was based on the use of equilibrium prices for the regulation of relations between the central and corporate sphere, on the plan redundance. According to Kodet (1964) competition could restrain monopolistic tendencies in a decentralised management model.

Truhlár (1964, p. 427) asked a question: "Where is the realization of all-people ownership? The enterprise interest is not a consequence of the limits of central management". According to Šik (1964, pp. 435, 445) "Truhlář created a scheme in which either market mechanism or directive planning existed. But instantaneous market development cannot decide on the basic production structure. Production for the market should be pushed as a substantial factor of plan elaboration".

Kouba (1964, pp. 476-477) contemplated about Kaigl's idea of science that examines processes taking place under people's control: "Society regulates the reproduction process and realises the set objectives without clash of market forces. The centre decides on the present and future by laying down the proportions of national income use." Červenková and Chyba (1966, pp. 152-153) were convinced that it was possible to argue with this illusion: "Socialist reality is an intentional creation, it can be conceived ex ante and finished in line with the original intention. But the human creation defies humans also in this case". Such a re-evaluation will assume the form of the "need of a new critical interpretation of socialism".

According to Kodet $(1965$, p. 3) "rules of game are legal regulations that should define the limits of business initiative development". Kouba stated (1965, pp. 296-297) that social priorities were provided by a contract between the centre and the enterprise and by legal regulations. Social interests were provided by the influence of the centre on investment allocation. Along with central institutions autonomous enterprises were participants in the elaboration of social development programme. According to Suchan (1965, pp. 334-337) the loan system influenced decisions of enterprises and national economy proportions. Kožušník (1965, p. 347) wrote about a mechanism that would transmit signals of changes in consumer demand and provided stimuli for fast responses of the trade and production sector. Kraus (1965, p. 805) was convinced that organizational forms should be maintained by the force of economy, not by administrative orders that could not distinguish different economic conditions in a satisfactory way.

Centralised management was to replace the functions of capital markets. Komenda wrote (1966, p. 771): "If this system had a perfect plan, its function would not differ from a functional market mechanism and its operation would be more perfect than the function of market mechanism." In four years that elapsed since Selucký's simplism Ptáček (1966, p. 939) asked this question: "To what extent is it possible to use the grouping of enterprises for joint investments and the system of buying and selling shares as a form of asset transfers?" Rychetník (1966, pp. 1064, 1065) answered this question in an article dealing with the use of welfare economics for socialist economy management: "I consider this approach as unsuitable in present conditions" but he accentuated the importance of ownership mobility of resources: "Monopolistic market will lead to an effective equilibrium state on condition that the free entry of manufacturers, e.g. producer cooperatives or small private producers, is maintained, and by supporting the economic and political force that poises the pressure of monopolistic producers in the market. It is a problem of democracy, political prudence and whether the interventions of the centre direct economy where the centre wants it to be." 
Novozámský (1966, p. 734) stated: "It is not possible to assume that conditions in CMEA countries will change so much (i.e. elimination of differences in the economic level of countries and tendencies to form closed complexes regardless of the effectiveness and improvement of purpose-oriented economic and political activity) that we can expect more effective coordination of development of the particular countries. Czechoslovakia should adapt its production structure to tendencies in CMEA countries and should not expect that structural changes would take place through coordination in the framework of CMEA."

A focus on theories of growth that are "theories of transformation of the social and economic structure and theories of relations between economic variables in the process of growth" (Janiš, 1966, p. 222) resulted in a model of the long-term growth of economy of the Czechoslovak Socialist Republic (CSSR) in which Cobb-Douglas production function and models of Harrod, Domar and Kalecký were applied (Tlustý-Strnad, 1965); it synthesised efforts aimed at a search for a more adequate position of social management and relation to standard economy. Tlustý (1966) published a model defining the conditions and prerequisites to achieve a certain type of future development.

Kýn and Müller (1965, pp. 114, 107) opened a discussion about non-Marxian economics: "It is useless to criticise bourgeois economists for the choice of methods and themes. Bourgeois economists depict real processes. The mechanism of capitalist economy consists in interactions of economic factors: demand-supply, profitwage, loan-interest rate, savings-investments, etc. We doubt about the validity of the equation: non-Marxian = not scientific". According to Roubal (1965, p. 572) "crucial problems of Marxian economics have been elaborated in detail; the external forms of economy have been paid less attention. In line with its programme bourgeois economics avoids crucial phenomena but elaborates in detail the external forms of economy development".

\section{Discussion about a Relationship between Poli- tics and Economy and about Economic Reform $(1967-1970)$}

The implementation of a new system made prices, wages, loans and stocks move. Macroeconomic disequilibria were concentrated in Slovakia (Turek, 1968), where the income situation of enterprises became worse (Turčan, 1968). According to Lantay (1968, p. 231) "the effect of market has a limited scope of influence. In connection with the implementation of a new system there appeared illusions about the effect of market mechanism".

Economic research was focused on the analysis of Czechoslovak economy development in the light of international comparison with the rest of the world, its theory and methods. Straub (1968, p. 1093) stated: "For the countries of Eastern Europe the equalization of the economic level with the West became a matter of existence. We are living in the state of siege due to relative technological underdevelopment. A low level of development maintains shortage, conflicts between various groups of society (and between socialist countries in general) and the sense of danger from the part of more advanced countries. In peacetime it leads to centralist forms of government with their negative impacts on life."

Using Solow-modified Cobb-Douglas production function Toms and Hájek (1967) deduced that in otherwise identical conditions the cause of different development of labour productivity should be sought in the positive or negative activity of non-investment parameters of national income growth. According to Toms and Klacek (1970) "the relation between output and labour negates the law of diminishing returns in a 
short period" (p. 1086). Štraub (1967, pp. 887, 890) formulated this opinion: "Investments in human resources pose a problem. Directive management made use of possibilities of postponing investments in the manufacture of consumer goods and in the non-productive sphere. It is a debt that has to be paid in the nearest future".

Fifteen years of discussions resulted in a critical approach to the development of Marxian orthodoxy: "The first to ask a question about a possibility of rational management under socialism and to provoke discussions about this theme were von Mises, Hayek and Robbins. Marxian theory failed to solve the relationship between plan and market and to develop a consistent theory of planning" (Hronovský, 1967, pp. 965, 961).

Economists studying the theory of the mechanism of economy functioning demonstrated that "the functioning of economy cannot be understood only through the categories plan and market" (Fišer, 1968, p. 831). A Club of Young Economists was founded at the Czechoslovak Economic Society (June 1968) and it was declared in its statement of policy (1968, pp. 882-883): "After criticism of the Stalinist concept of economics Šik's School presented arguments based on the structure of interests and on demands for solutions to physical problems of national economy. This approach to economic policy was not successful because Marxian economics was not conceived as the theory of national economy and economic policy. Theory has to acquire consistency or economics should be divided into political economy of Marxian type and national economy science (positive theory of the functioning of economy)."

Statements about the need of revising the attitude to Marxian economics were elaborated in discussions about value. According to Klaus (1967, pp. 128-129) "any jump in the theory evokes discussions about value. Because Marxian economics in the sixties is of such a jump, the problem of the labour theory of value appears again. A different task is assigned to research on an economic system to prove the lack of its effectiveness. An economist who tries to find an optimum rate of national economy growth is assigned another task." Budínová (1968, pp. 821, 828) asked: "What is the cognitive value of the labour theory of value and theories based on the productivity of factors of production?" Toms (1967, pp. 1044-1059) pointed to the assumptions of the labour theory of value and to a possibility of their weakening. He demonstrated that under these conditions the labour theory of value was consistent. Only labour is a limited resource in a long period.

A prologue to discussions in 1967 - 1970 about the relationship between politics and economy on a national and international (CMEA) scale and about the relationship between the centre and enterprises, and consequently about inflation pressures, was a proposition formulated by Fišer and Kýn (1967, p. 717) when they terminated research on the limits of the functioning of market mechanism in the conditions of nationalization of factors of production: "If society cannot confide to its defined elements the role to carry out business activities and the role to bear ensuing risks and to establish economic agents of a functioning market, a deformed market arises where enterprises share the profit and losses are incurred by society."

An issue of the correlation between politics and economy was raised by Sláma (1967, pp. 233, 235-236), who argued against Rychetník's and Kýn's (1966) opinions concerning the relationship of political and economic criteria during optimisation of economic development and the role of science in this process; they considered science based on the definition of optimisation criteria as technocracy and recommended to obtain these criteria by surveying and harmonization of preferences of the population: "A conflict between capitalism and socialism will be decided by the effectiveness of both systems. The formation of socialist economic structure depends on political movement. The task of politics is to lead society on the basis of better and better known developmental regularities and in the direction of these 
developmental regularities, and to take into account the subjective maturity of society aiming at its enhancement."

According to Rybáčková (1967, p. 175) "the market mechanism in the period of New Economic Policy was a result of intentions of the Soviet government declared after the Revolution". Hronovský (1967, p. 490) "could not understand that Mrs. Rybáčková did not mention that a concept negating the market mechanism was at the cradle of socialism." The same author (1967, p. 968) wrote in this context: "If in the conditions of non-goods economy the immediate interest of working class (removal of exploitation) seemed to be realisable, it is obvious that in these conditions the longterm interest of working class - rational management - cannot be realised."

Korda $(1967$, pp. $670,669,671,673)$ wrote: "We can plan controllable variables. We wanted to subject to the control more than our knowledge and experience could cope with. We abolished the functioning institutions including market without knowing whether the substitution would work. The social function of utility is a result of democratic compromise of different preferences of various persons and groups. The choice of a criterion is a matter of political decision. The economist's task is to analyse consequences of this or that choice."

Sláma was supported by Kouba (1967, p. 781) when he stated: "Socialist economy exceeds the framework of the market system. Socialism is developed as a system with higher target behaviour". According to Rychetník (1968, pp. 347-353) "society management evokes a question who is authorised to take decision on preferences. In democracies the authority is transferred to a parliament or government. How to ensure that the voice of the group of more powerful members of society would not be louder than that of the others? The effort to manage economy is the expression of a conviction that the economic process is not predetermined, that the subject (organised human society) has a choice within a definite space of freedom. A politician as well as the opposition may try to change the society's opinion by a propagation campaign. If the situation does not change, nothing else can be done than to revise one's own proposals or the politician is replaced by another politician with different policy. I want to draw attention to the real danger of one-party system. Small private businesses may play a positive role in this country in the renewal of competitive market environment and economy recovery, but employment by private owners cannot be allowed. It impedes the expansion of private workshops into larger firms and makes economists verify other ways attractive for owners of workshops."

Developing Kaigl's doctrine Sláma and Štraub (1968, pp. 431-436) asked a question what the development of Czechoslovak economy would be like without suppression of market and market behaviour of individual capitals and with a regulating influence of the state. "In order to enforce political priorities it was not necessary to suppress the market behaviour of their particular elements to such an extent as it happened. But the internal and international political situation in Czechoslovakia was much more complicated and difficult." Hrnčír (1968, pp. 633-639) noted: "The declaration of rouble convertibility cannot be expected. There is an alternative of the autonomous procedure of Czechoslovak economy and Czechoslovak currency to convertibility".

Along with Kraus (1964, p. 871) economists asked how long the support of the social centre to their efforts to increase economy performance might last, why it could not do so and why it would not be able to do so. Čížkovský's question (1968, p. 481) was a modification of Kraus's question about the ability of the political sphere to reform a management system on an international scale: "Can an organ such as CMEA play an active role in the reconstruction of management system in member countries and their national economic structures using modern instruments to accelerate this reconstruction?"

Discussions about the rational behaviour of enterprises agreed on the fact that the establishment of boards of workers and self-management led to the decontrol of enterprises and that self-managing, state, cooperative and private enterprises must exist parallelly. There was still a question whether profit (will all its limitations) must be a criterion of the rational behaviour of an enterprise. According to Kreuter self-management was justified in small enterprises while in large enterprises a selfmanagement organ could be established only formally, but its behaviour need not 
be short-sighted. Mlčoch thought that long-term decisions were Achilles' heel of proposals. Without capital market we cannot speak about the market mechanism; the state cannot take over its functions. Kožušník formulated this theorem: "Even though we permitted that a part of the assets would be sold to the population, the savings of the population (the only fund available for this purpose) are about a ninth of this amount" (see Mlčoch, 1969, p. 281). The problem of mass privatization methods was raised.

Vencovský (1967) compared the mechanism and effectiveness of granting credits by a monobank (cheap operation) with the mechanism and effectiveness of a system of commercial banks. According to Kocanda and Pelikán (1967, pp. 93, 120) "standard economics asks along with B. Ward: Will the behaviour of enterprises (working groups) in market relations be similarly rational in socialist economy like in capitalist economy? The assumed difference (to employ only the workers who will produce a higher increment of gross income than their basic wage, and also a share of profits) is possible to eliminate. If they are self-managing enterprises in a real market, it is possible to differentiate remuneration of existing and new workers. After this adjustment the socialist market system does not have a flaw in an abstract model from the aspect of rational behaviour of enterprises that would difference it negatively from the capitalist system. We can expect the effects of the more efficient social regulation and development of business initiative (producers, etc.) that would result in more favourable development of economy than it is probably in capitalism. We can speak about the advantages of centrally planned regulation in a socialist market model only if it is proved that this model does not have a flaw in general decisions of enterprises in the market. Market is a platform on which central regulation is applied." Ernst (1968, pp. 782-785) wrote: "The establishment of corporate or managing boards, uncontrolled dismissal of directors and managers and pressure from the corporate sphere accentuate the need of institutional solutions. Horálek, Kožušník, Sokol and Turek apply the knowledge of operations of capitalist economies (money market, stock market, etc.) to such an extent in what they correspond to the character of socialist economy. On the contrary, Klaus considered the maintenance of the social ownership of factors of production and distribution according to work as an ideological prejudice, Ježek considered it as a logical mistake and Šillar as a dogma. A new system of management evokes a question who the subject of the enterprise from the ownership aspect is, who appropriates its concrete results to oneself." Vostatek (1969, pp. 314-316) expressed this opinion: "A question asking about the form of capital market is rather complicated. The state has to influence the level of accumulation and interest rates. A majority of capital should be held by the state as the largest entrepreneur. If the state is to have a return on its capital depending on the performance of an enterprise, the efficient pressure of the state on the highest possible effectiveness of corporate capital (as a counterbalance to the pressure to increase employees' incomes) can hardly be assumed. Therefore it is necessary to maintain the private ownership of corporate capital, the magnitude of which should be defined quite exactly; a single individual must be prevented from capturing the (economic) power above the company." According to Malypetr (1969, p. 238) "the prices of factors of production should be a result of a certain form of market. Its existence may become a part of central (not directive) management on condition that the state as a representative of social interests is the main seller and business organizations representing group interests are buyers. Perhaps we should speak about lease".

Turek (1970, pp. 609,620) rejected the responsibility of research for the process of economic reform. He was convinced that "an emphasis is laid on two principles: enterprises should earn their own living and they must live in a challenging environment. In fact the habitual behaviour of the centre and enterprises continued: negotiations about conditions determining the income position of the enterprise. Harmful effects of these efforts were larger than in a directive system. As there existed no initiative of the centre that would set down the regime of doing away with income improvement, enterprises were able to influence subsidising and tax policy."

While Kř́ž (1968, p. 531) was pleased by "the fact that the 150th anniversary of Marx's birthday was celebrated in the conditions giving hope that heaped deformations would be overcome successfully and after malign products of the Stalinist concept had been removed it would be possi- 
ble to develop Marx's legacy", some time later Nachtigal (1969, p. 377) commented with bitterness the delayed edition of Statistical Yearbook of the CSSR: "If this delay were the only negative consequence of turbulent events of the last year, we could be happy. We find new data lists and data here. Let us hope that the development in the CSSR in the second half of the last year and in this year will not lead to a hold-up of other data release."

Slackening efforts for the economic reform were due to internal (position of Slovak economy, inflation processes, behaviour of decision-making structures) and external (international isolation) causes. Říha (1970, p. 386) and Olšovský (1970, p. 580) spoke about problems that "arose in national economy in $1968-1969$, when imbalance increased and central planning was debilitated, which complicated the economic situation; therefore the losses incurred in these years must be repaired." These processes and their political and economic perception were reflected in a change in economic research orientation.

\section{Fight Against Revisionism and Opportunism and J. Goldmann's Propositions (1971 - 1978)}

The development of economic theory in the second half of the sixties of the $20^{\text {th }}$ century that was characterised by a divergence from the orthodoxy of directive planning and when competitive research programmes of theoreticians and publicists struggling for their audience were published, started to be perceived falsely as a coordinated and organised process (see Jirka-Srba, 1972, p. 640) intentionally undermining the socialist economy. It was only after 1979 when there appeared signs of a more positive approach to the thinking of economists in the sixties of the last century (1980, p. 284).

Principal objections to revisionism may be summed up in this way: "Management of economy passes from plan to market. With transition to the market mechanism as a principle of socialist economy and with development of particular markets allpeople ownership disappears and right-oriented economists substitute corporate ownership for it. The market mechanism of economy was to be applied to foreign trade, investment market, market of production consumption, labour market, money market and capital market. The state was transformed to one of the market participants. Capitalist economy was becoming a model" (1972, pp. 842, 808, 823).

In the fifties the society was forced on, either voluntarily or obligatorily, subordination to the leadership of Communist Party of Czechoslovakia (CPC) but Kočís postulate took effect. This process continued in the seventies, when the economic behaviour of civic society markedly emancipated from the CPC and government. This process was interpreted as society's consolidation (normalization) but economists pointed to its lability.

Adamíček (1972, p. 602) dealing with the relationship between planning priorities and individual preferences wrote: "Consumers' position was strengthened and the ability to manoeuvre increased (postpone consumption, make unexpected substitutions). The economy becomes less stable due its greater dependence on individual consumption, and it is more difficult for planners to depict the process of formation and realisation of the population's consumption." Ježek (1976, pp. 328-329) stated: "Difficult predictability of costs of innovation introducted into the production process and innovation effects is a barrier to the activity of enterprises. Directive plan makes it necessary to foresee the level of costs and profit. In a nonstochastic concept of planned economy wages as a decisive component of the population's demand are an extraneous element - consumer is an economic agent who competes with the centre in decisions on the allocation of resources".

Rybáčková (1971, pp. 497-498) wrote: "In the economy where economic agents can decide on a part of savings it is necessary to distinguish ex ante equilibrium and ex post balance equality. The accumulation defined by the planning centre has different sources: 1) ex ante planned centra- 
lised savings; 2) population's savings determined more or less behaviourally. The level of the population's savings is a crucial variable that funds the credit-based part of demand for investments. The share of the population's savings in the funding of investment credits increased from $45 \%$ in 1967 to $80 \%$ in 1970 . The ex-ante estimated level of savings is a sort of prognosis due to its specific determination".

According to Fogl (1974, p. 819), who examined the relationship between economic policy and consumer's behaviour, "savings can be considered as subjective decisions of individuals between the creation of savings on the one hand and consumption on the other hand".

Applying these analyses economists wanted to define the rules of price setting on the basis of the type of prices (Kasan, 1974; Kotulan, 1975; Soukup, 1976). This approach led to a consideration about the relationship between prices and stimulation of innovative activity in the khozraschot sphere (Soukup, 1978).

Roubal (1971, p. 397) accentuated that the problem of national economy development in the sense of Marxian theory of the national economy optimum was set as an issue of targets and their criteria, as an issue of resources and their mobilization and allocation and as an issue of mechanisms of the economic system functioning. Ježek (1977, pp. 754-759) argued against this hypothesis; he was convinced that the utilisation of labour resources of the society was an intersection of the optima of agents that participated in the economic process, and so it was useless to seek an optimum level of utilization of labour resources of the society.

Hrnčiř's opinion (1973, pp. 981-990) was as follows: "The Czechoslovak economy is not shaped by planning, ex ante, as a functionally open economy in which parameters of the external environment are respected. The development of costs, productivity, technological advance, structure of needs and demand is stochastic. Uncertainty of information increases with the extension of the time horizon. Accentuation of superior quality products is the best way of tackling uncertainty. The open economy solves the problem of uncertainty about the external environment more efficiently than the non-open system to the extent in what it is a tool of structuring economy for production and export."

Goldmann (1974, pp. 482, 488) advocated a proposition how to overcome Indra's periodic difficulties: "The development of economy is characterised by the stable dynamics of growth of national income and industrial production that has been maintained on this level for several years". Goldmann also discovered development discontinuities (price fluctuations in international markets, conditions of cooperation with CMEA countries and increased level of investments) and wrote: "The possibility of stability of growth process in future is not identical to the certainty of such process. Transitions from equilibrium to disequilibrium are caused by marginal variables. Sensitivity to marginal shifts is given by stability or instability of the economic situation as it is manifested on the level of consumers. Therefore it is worth analysing reactions of consumers, their attitudes and expectations. In the conditions of increased investments, less favourable exchange relations, behaviour of consumers and enterprises this possibility accentuates the role of stabilization policy. The goal is to support equilibrium tendencies in economy, especially in the consumer market." Goldmann (1975, p. 1) argued with the intentions of central planners: "Analyses of relations between macro-variables in time signal changes in economy tendencies. Economy could be in contradiction with new internal and external conditions if the forces of inertia afflicted the capacity to react flexibly to changing external conditions and internal barriers (depletion of labour resources, material and energy requirements, underdevelopment of services and environment condition)".

In this context analyses of plan failures became more important. Izák (1978, pp. 589-592) reflected Misař's finding of limited capacities of directive plan (1963): "In terms of balance extensively developing economy without structural changes, technological advance and with perfect information system would be ideal. Planning of production by the centre is feasible only in the group nomenclature". Šrein and No- 
votný (1979) complemented Izák's analysis of the objective aspect of plan failure by the analysis of subjective decisions of a central planner. They noticed that the accent on efficiency aspects in systems of material interest that resulted in the deflexion of production from the intentions of central plan was given by a disharmony between preferences of central plan, relative prices and material interest. Hrnčír and Nachtigal (1978, pp. 779-780) wrote: "Positive effects of external relations on the level and rate of national income growth are not produced automatically. It is a matter of the institutional organization and mechanism of national economy. Rational allocation of resources can be implemented on condition that it has an effective carrier."

Klaus and Rudlovčák $(1977,1978)$ published a pronouncement on the importance of empirical testing of explicitly formulated economic theory. Their approach differed from the approaches of Goldmann and his adherents who promoted so-called macroanalytical approach: "Accumulation of data is a pledge, not an actual fortune. Mathematization and formalization of theory without a new and deeper insight into the functioning of economy is not a progress as it is usually declared. There exists a different approach that is based on empirical testing of explicitly formulated economic theory and that is more perfect than pure empiricism or general theory, or the intuition of an individual. Such a theory is a framework for quantitative analysis and prognosis of the state and movement of aggregate economic variables in a short period."

\section{5. "Perestroika” and Market Mechanism (1979 - 1989 )}

Klaus's approach (1980, p. 697) was based on this statement: "The first stage of model development is economic theory of the functioning of socialist economy (theory of normative, and particularly positive, descriptive type), mathematical instruments used for the rigorous formulation of theory and for numerical operations with data, statistical methods enabling to interconnect the relationships of theory with real data loaded with noise, economic data and computer technology."

In the framework of implementation of this programme Klaus and Rudlovčák (1982, p. 418) analysed rational expectations of individuals: "In the past savings were considered to mean a difference between disposable incomes and realised consumer spending. Currently, the examination of savings is accentuated. The point is to distinguish a normal component and a transitory component of the population's incomes. If the growth rate of incomes in the CSSR in $1966-1979$ was higher than expected (5.16\%), transitorily higher incomes were deposited as savings (i.e. in 1966 - 1974 except 1970), if not, savings were lower (1975-1979)." Klaus and Tríska (1988) described a model of socialist economy in relation to the reconstruction of economic mechanism using the language of standard economics.

Unlike Klaus, Křížek (1983, pp. 228, 230) formulated tasks for economic theory in a different way: "Until the level of knowledge profundity in political economy of socialism matches the level in Marx's Capital for capitalism, we cannot speak about the scientific knowledge of socialism". In the sense of Kaigl's and Kouba's approaches Hába (1987, pp. 1121-1122) confronted the legacy of Bolshevik Revolution and development of the management system in the USSR: "Reconstruction grows from the ideological roots of October Revolution. After nationalization the economic sphere is subject to the state control that tends to enforce methods not suitable for economy. Prescriptions foresee any situation, and economic methods involve risks."

Rumler (1979, p. 338) wrote: "Development of science and education outreaches the capacities of monopoly capital and its particular groups, or it reaches beyond 
its capacities by the vagueness and riskiness of its outputs, so this duty cannot pass (to a limited extent) to anyone else than to the state." Gürlichová (1979) noted that bourgeois theory examined the problems of resources, consequences and types of technological advance. Responding to these challenges Hába (1979) opened a discussion about scientific and technical revolution (STR).

Mervart (1979, p. 1034) wrote: "The process of STR must overcome an administrative labyrinth, which creates the atmosphere where routine prevails and where the certainty of unchanged existence debilitates the spirit of enterprise". Bureš and Mejstř́ík (1985, p. 982) asked a question: "To what extent can the applied instruments of planned management generate, avoid or regulate risks, to what extent can they positively influence the risk admissible behaviour of a khozraschot unit in the process of innovation revelation?" Lukas (1987) diverted the discussion beyond the boundary of Marxian-Leninist orthodoxy based on the determination of an individual's activity by the existing forces of production and relations toward standard economy with its discussions about the liberty of an individual's choice, and he examined the development of economic structure as an external consequence of individual decisions.

Chytil (1980, pp. 177-178) believed that the market mechanism where equilibrium was established by variations of prices from the value was replaced by the intentional attainment of proportions without trials and errors. The centre should take such decisions that would not disturb the principle of effectiveness. If this fact was not respected, social losses might be incurred (in the area of investments negative impacts might be obvious in several years due to a time lag). Disproportions might also arise in a period of success.

Pastrňák (1981) proved that the necessity to convert criteria of economic agents' behaviour effectiveness to parameters to the fulfilment of which wages and profits were related was a deficiency of central management. According to Hába (1983, p. 1251) the idea of planned management assumed that "national economy was governed by the fixed order enabling to foresee future consequences of present causes with relative certainty." Klusoň (1983, p. 1291) warned: "Changes in world economy will be more frequent and more marked, they will require effective responses." Soukup's (1984) statement about the need to solve an information problem as a background to harmonise natural and value relations was complemented by Fogl (1985, pp. 590, 592): "Only such an organization of economy can be efficient that is based on observation of partial interests, on their coordination and harmonization in favour of the whole. The information problem does not consist in centralization of information but in its rational allocation between relevant economic agents and levels of management (decisions). Central planning and information flows depend on the real structure of interests. The price mediating payment relations cannot be a tool of management in the traditional sense if it has to reflect objective reality."

Dlouhý and Dyba (1985, p. 139) reformulated Kočís postulation: "Institutional characteristics of socialist economy specify the definition of internal equilibrium. Capital goods, goods for export and for social consumption are allocated by the centre in physical quantities. Planning organs set down the aggregate supply of consumer goods and their prices. Consumers spend their incomes for these goods on the basis of their consideration. Planning organs set down demand for the flow of labour input and wage tariffs, and households decide on labour input." According to Truhlár (1986) the problem is in the content and effectiveness of central plan, in its adaptability to economic assumptions of different links of economy, in its stimulating instruments. The business nature of economic activities and its parametric character are unthinkable without the social mechanism of its check-up. Participants in social production cannot be indifferent toward the value, toward the optimum of social labour conditioning the quantity and growth of material utility values. They 
must be sovereign customers and suppliers. Rendek (1987a,b) elaborated in detail Lange's idea concerning planners who can set rational prices on the basis of competition of enterprises for inclusion in the plan that should eliminate inefficient quotations. As the world market approaches the conditions of free competition, prices should be derived from world prices. But Soukup (1987, p. 712) wrote: "Foreign price relations cannot be taken over into the domestic price system from the aspect of either physical or institutional structure of Czechoslovak economy". In addition, Halaxa (1988, p. 522) stated: "Private manufacturers do not tell the information on costs and profit".

Klusoň $(1987$, p. $570 ; 1988$, pp. 4,15$)$ advocated this idea: "It is not possible to maintain the concept of management based on the application of special rules and direct instruments of management and to neglect general rules linking up relatively autonomous units and creating the functioning whole of national economy. The task of the centre is to apply the rules that do not say what will happen in definite circumstances, but what may not and cannot happen. It will eliminate undesirable segments of the variety of controlled units but there will be a space for the behaviour stimulating growth in desirable directions."

Rusmich (1988, p. 51) wrote: "It is a transformation of the behaviour of participants in the reproduction process - from fulfilment of tasks assigned from the top to creation of socially rational innovations". Machová (1988, pp. 63-64) attempted to define the limits of this change: "Enterprises are not owners of assets under socialism. They cannot transfer them freely, i.e. on the basis of profit criteria and market situation, into other industries. The functioning of market mechanisms are conditioned by the type of social relations and conditions. The system of management cannot return to price setting that was characteristic of private production and uncontrolled market mechanism, i.e. abandon prices as a social norm and leave their level to a free agreement of partners according to their economic power and market situation. Enterprises may change the orientation of their production only in the framework of the given concept of the planned management system."

Soukup and Seják (1988, p. 472) formulated this idea: "Foreign prices or decentralised price setting can contribute to the creation of a system of criteria prices. But they cannot create the parametric environment that would require effective production." Contrary to Bakalár (1988), who wrote that in the stage of acceleration of social and economic development it was possible to proceed to a more complicated system of banks and after the physical problems of economy had been solved it would be possible to establish one bank in a further stage (p. 494), Klaus (1988) argued in detail for Spišiak's idea (1960) about the separation of monetary centre from planning centre and for the idea of Kožušník (1965) and Vencovský (1967) to establish a system of commercial banks.

Hlaváček, Kysilka and Zieleniec (1988, pp. 593-604) argued against this proposition: "Reduced capacity of national economy to generate important information on its functioning is a consequence of the conflict of interests arising from central decisions on the use of resources. The fact that some mechanisms acted on the verge of law when they failed to get in the focus of interests of institutions responsible for economy functioning documents an important system characteristic that oppresses such mechanisms, aversion to measurements or aversion to information that would enable to measure the performance of participants in the reproduction process".

Comparing economy development in Hungary and Czechoslovakia Dyba (1988, p. 676) draw a conclusion: "The reform is a necessary but not sufficient condition so that the performance of reformed economy will be higher in comparison with traditionally managed economy. The reform must be accompanied by pro-reform strategy 
and policy and favourable external economic environment. Economic reform cannot be successful without social and political reforms".

Vencovský (1988, pp. 1010-1013) discussed about currency convertibility: "Free convertibility of Czechoslovak koruna is one of the elements of market economy. A tendency of equilibrium toward foreign currencies depends on the potential of the CSSR position in international labour division when domestic production must have such technical and economic parameters that correspond to criteria of markets on which the koruna should be accepted. It is convertibility of goods that leads to koruna convertibility."

Klusoň (1988, pp. 1124, 1136) formulated this opinion: "Reconstruction of the economic mechanism is influenced by the application of principles of social ownership of factors of production, state plan setting down material proportions, cost prices, administratively controlled mobility of resources, paternalism of the state, guarantees of a large part of wage and right to work. It is necessary to demonopolise economy through competition, to accept the idea of responsibility for results of work and decisions, idea of strict budget restriction, prices as exogenous variable, contractual planning and support to mobility of financial resources in the market that will allow enterprises and population to buy bonds, and purchase and sale of shares restricted to the state and cooperative sector. The proportions of ownership sectors will change in future."

Articles analysing development of Czechoslovak economy and considering the development of internal and external economic conditions after 1973 as the breakpoint were milestones leading to this ideological breakthrough. Vintrová (1981, pp. 913-914) wrote: "Comparative effectiveness of Czechoslovak economy in relation to the rest of the world decreased. As the valorisation of imported inputs through exported outputs is lower by a fifth and because these transactions account for a third of the national income, a fifteenth of the national income is lost from domestic use in favour of the external world compared to the conditions on which living standard and production development were based in the early seventies. In the eighties economic impacts cause shifts in international political relations. The increased international tension brings costs of armament programmes, disturbs economic relations and evokes political uncertainty. Disturbances in Polish economy influence the other countries of CMEA."

Vintrová (1984) wrote about the vicious circle of stagnant economy. According to Kupka (1985, p. 245) long-term growth is not possible without equilibrium and effectiveness. The choice of growth rate is between the increased tension and increased failure to use resources. Adaptation to external impacts requires an energetic response of economic policy that cannot be conceived any longer as a package of partial measures complementing the tasks of state plan. Since 1985 efforts to describe development of Czechoslovak economy in international comparison were accompanied by a discussion about its economic performance, i.e. about the level of gross domestic product (Komárek, 1985).

\section{Marxian and Standard Economics}

Since when the Politická ekonomie journal started to be published, governing orthodoxy was disturbed from time to time. Its critics (Burešová, Červinka, Kraus, Myliveček, Stočes) and critics of this criticism (Braník, Kaigl, Oliva, Šik) were made to re-orientate the style of their thinking. These germs of different thinking originated as a result of partial research programmes (productivity, economics of agriculture and trade). In general, this shift - from the need to respect the law of value (Kraus) to the need of economic reform (Červinka) - was evoked by discussions of 
theoreticians and by development in capitalist and socialist countries. Directive economy was not perceived any more as a magic wand to solve problems (see Sokol, 1957, p. 37). Social structures defending the given order established themselves. Šik wrote: "All-people's interest will be formulated in greater detail by the Party and government and will be reflected in economic plans most markedly" (see Petrovský, 1957, p. 219).

In the sixties of the last century economic science in the CSSR became an institutionalised scientific discipline that accepted a definite paradigm but was more and more open to standard economy and international scientific community. In this context the interpretation of Engliš's theory (Nikl, 1960) can be appreciated when Engliš was designated as one of the most important Czechoslovak economists. Economists successfully argued against so-called hard core of governing orthodoxy (Kadlec's theorem) and revealed that planned economy might be an economy rationally allocating resources (Koči's theorem), even though through disproportions (Kraus's theorem), depending on how decisions of an individual on the consumption and allocation of his/her human capital influence decisions of the centre. Families take decisions whether women will be employed or not, how and where their members will work, how much money they will save, etc. and the centre should learn to adapt itself to these several plans of individuals (Kadlec's theorem and Rypota's improvement).

In the second half of the sixties economists contemplated about the importance of capital markets and private ownership (e.g. in the form of private labour expended with higher effectiveness than socialised labour in cooperatives) for the functioning of market mechanism. Revival of economy as science was terminated. There were only some smudges in this picture, labelling of ideological opponents (dogmatism), Kaigl's and Kouba's illusion, somewhat simplistic concept of market mechanism, temporary support to the decision sphere given by the centre's interest in restoration of its capacity for action and by the interest of enterprises in price reconstruction. Divergent tendencies appeared in member countries of CMEA. This process was accelerated by attempts of particular countries to carry out an economic reform, but its international scientific and political background did not exist, which brought about gaps in the external safety zone of the USSR.

In the theory of transformation of economic structures economic theory in the late sixties of the $20^{\text {th }}$ century achieved the limits that were overcome in the nineties of the $20^{\text {th }}$ century. These limits were defined by the idea of convergence. If Vostatek set down the elimination of a threat of the individual's getting control of the society as a condition for the extent of private ownership, he defined the importance of democracy and anti-monopoly policy for the maintenance of market environment. The result of Kýn's and Müller's research (1964) was that the opinion concerning impracticality of Marxian political economy became popular among economists. On the other hand, the importance of analytical means of neoclassical economics was emphasised. In agreement with this stream authors advocating quantitative economic theory published their opinions in the Politická economie journal (Ernst, 1970, p. 806).

Goldmann's publication activity can be considered as a further watershed in the process of economics emancipation from the decision sphere. This created a space for the approaches of Klaus, Rudlovčák and other economists based on empirical testing of explicitly formulated economic theory. The eighties were a period of the decay of Marxian-Leninist political economy with its categories and laws as a governing ideological paradigm bound to socialism and its economy (ideological collectivism) and a period of the onset of standard economics and its scenarios with 
its models and rules (ideological individualism) that elaborated a more realistic model of the (non)functioning of centrally planned economy.

Komárek (1989, p. 524) wrote an obituary of Marxian-Leninist political economy: "The idea of the functions of socialist economy on the basis of coexistence of objective economic laws of socialism collapsed in the ideological climate of perestroika in the USSR and under the weight of historical facts. The formulation of theoretical propositions was based on long-term tendencies and their speculative generalization that were considered as regularities acting in favour of socialism. These approaches made the Czechoslovak theory increasingly more subjective, and it entered from the 'realm of speculations' to the 'realm of reality' with laws and rules formulated in advance".

The approaches of Komárek and other authors can be summarised as follows: "Society regulates market in a planned way and market regulates enterprises. The creation of conditions for real market functioning also applies to the revival of all functions of socialist ownership, development of modern forms of working people's participation in the management of enterprises. The cooperative sector traditions and individual and private business initiative that cannot be ignored in real contact with world markets must be a part of these changes. If the world economy is based on the existence of a number of ownership forms while private ownership has a dominant position, the open economy of a country that wants to be successful on an international scale cannot do anything else than to respect private ownership, activities of foreign firms and their domestic affiliations or hybrids" (1989, pp. 527, 534).

Klaus wrote: "If we omit the problem of market structure, the reconstruction of an economic mechanism primarily implies the reconstruction of the centre ... The economic centre should see what one producer (or one consumer) does not see, it should see so-called externalities that are evoked by the economic activity of one economic agent towards other economic agents" (1989, pp. 570, 571).

Turek and Ježek stated: "Pursuing their own aims and applying their own knowledge, economic agents are governed by monetary information in which almost all substantial that matters is contained in a condensed form: limited incomes tell them that economic resources are limited while prices indicate the relative intensity of these limitations of resources and consumers' preferences. The observation of impersonal monetary criteria provided by the economic system as a whole ensures the social nature of partial behaviour" (1989, p. 581).

\section{References}

Politická ekonomie, volumes 1953 - 1989 (quotations have been adapted and shortened for more clear arrangement and better style).

Řezník, J.: "History of the Politická ekonomie Journal." (in Czech). Politická ekonomie, 2003, No. 16, pp. 29-39, 147-172, 307-327, 451-503, 611-660, 771-824.

Selucký, R.: Economy, Morality, Life (in Czech). Prague: Československý spisovatel 1963. 